\title{
Influence of agronomic conditions on the efficacy of different fungicides applied to wheat at heading: effect on flag leaf senescence, Fusarium head blight attack, grain yield and deoxynivalenol contamination
}

\author{
Massimo Blandino, ${ }^{1}$ Michelangelo Pascale, ${ }^{2}$ Miriam Haidukowski, ${ }^{2}$ Amedeo Reyneri ${ }^{1}$ \\ ${ }^{1}$ Dipartimento di Agronomia, Selvicoltura e Gestione del Territorio, Università di Torino, \\ Grugliasco; ${ }^{2}$ Institute of Sciences of Food Production (ISPA), National Research Council (CNR), \\ Bari, Italy
}

\begin{abstract}
A series of field experiments has been conducted in North West Italy over a period of 3 years to evaluate the effect of fungicide applications on common wheat yield and safety, combined with different agronomic conditions (high: a susceptible variety to FHB planted in an untilled field; low: a medium tolerant variety to FHB planted in a ploughed field) for Fusarium head blight (FHB) infection risk. A azole mixture (prochloraz + epoxiconazole), applied at heading, was compared in each year and for each agronomic condition with a triazole with high activity against $F$. graminearum and $F$. culmorum (metconazole), a strobilurin-azole mixture with elevated action to control leaf diseases and delay leaf senescence (azoxystrobin + prochloraz) and an untreated control. The following parameters were analyzed: flag leaf greenness, grain yield, test weight, thousand kernel weight (TKW), FHB incidence and severity and deoxynivalenol (DON) contamination.

The results of this research, conducted over three years with different meteorological conditions, underline the important link between fungicide efficacy and environmental and agronomic conditions that can influence fungal disease pressure. The fungicide effect on the con-
\end{abstract}

\footnotetext{
Correspondence: Massimo Blandino, Dipartimento di Agronomia, Selvicoltura e Gestione del Territorio, Università di Torino, via Leonardo Da Vinci 44, 10095 Grugliasco (T0), Italy.

Tel. +39.011.6708895 - Fax: +39.011 .6708798 .

E-mail: massimo.blandino@unito.it

Key words: deoxynivalenol, fungicide, Fusarium Head Blight, strobilurin, triazole, wheat.

Acknowledgements: the authors would like to thank Fabio Carnaroglio, Mattia Ciro Mancini, Alessandro Peila and Francesca Vanara for their precious help and cooperation in the laboratory and field work. The research was conducted with the financial support of the Regione Lombardia, as a part of the MICOCER interregional project.

Received for publication: 26 July 2011.

Accepted for publication: 18 October 2011.

(C) Copyright M. Blandino et al., 2011

Licensee PAGEPress, Italy

Italian Journal of Agronomy 2011; 6:e32

doi:10.4081/ija.2011.e32

This work is licensed under a Creative Commons Attribution NonCommercial 3.0 License (CC BY-NC 3.0).
}

trol of FHB and the increase in flag leaf longevity and grain yield were greater with an increase in the disease pressure. On the other hand, the DON contamination was reduced by the fungicide to a greater extent in the low risk agronomic and environmental conditions compared to the high risk ones. Prochloraz + epoxiconazole showed a lower efficacy in reducing DON contamination compared to metconazole, particularly in the higher FHB pressure conditions. No significant differences were observed between the azole mixture and the strobilurin-azole mixture for flag leaf greenness, grain yield, test weight or TKW. This study provides useful information that can be used to evaluate, in naturally-infected field conditions, the effect of a fungicide application at heading on wheat yield and safety in distinct scenarios for FHB and foliar disease pressure.

\section{Introduction}

The application of fungicides to wheat (Triticum aestivum L.) canopy from heading to anthesis could be an essential practice to reduce yield loss due to fungal diseases attacking ears and leaves (Mesterházy et al., 2003; Ransom and McMullen, 2008).

Fusarium Head Blight (FHB) is the most widespread ear wheat disease and it could be caused by a variety of fungi, including Microdochium nivale and different Fusarium species (Champeil et al., 2004a). This disease causes total or partial ear premature senescence with a consequent reduction in both crop yields and grain quality. $F$. graminearum and $F$. culmorum, the most important FHB agents, are also the main causes of the accumulation of the type-B trichothecenes deoxynivalenol (DON), which is associated with serious mycotoxicosis in humans and animals (Bottalico and Perrone, 2002).

In addition to FHB, several other wheat foliar diseases could also severely reduce grain yield and quality, due to a reduction canopy photosynthetic life, which is of particular importance for flag leaf during grain filling (Richards, 2000). The leaf spot complex (caused mainly by Septoria tritici, Stagonospora nodorum and Drechslera tritici-repentis), powdery mildew (Blumeria graminis f.s. tritici) and rusts (Puccinia spp.) are the most common foliar diseases throughout the world (Robert et al., 2004).

The most important preventive measures for both ear and foliar diseases are: to minimize the pathogen inocula in the field by using crop rotation (Champeil et al., 2004b, Krupinsky et al., 2004), to reduce previous crop residues through soil tillage (Maiorano et al., 2008) or to use resistant varieties (Loyce et al., 2008; Tóth et al., 2008). However, in climatic conditions conductive to fungal diseases, the above preventive measures could be not insufficient and direct control through the use of fungicide application are necessary (McMullen et al., 2008). 
Fungicides containing triazole, imidazole or triazolinthione active ingredients, which inhibit the biosynthesis of ergosterol, have proved to be the most active molecules for the control of FHB infection and the consequent DON contamination (Paul et al., 2008). However, the use of azole fungicides for FHB control and DON grain accumulation led to different results (Edwards et al., 2001). In some naturally infected trials the application of azoles significantly reduced FHB symptoms, but did not affect DON contamination (Milus and Parsons, 1994). Metconazole, prothioconazole and tebuconazole have been reported to be the most effective fungicides for the control of Fusarium spp. and reducing the level of the main mycotoxins that occur in cereal grain (Pirgozliev et al., 2002; Klix et al., 2007; Paul et al., 2008). Azoles, which are primarily applied at heading beside FHB control and reduction of DON contamination (Pirgozliev et al., 2008), also resulted to have a significant effect on the reduction in the decline of the green leaf area in flag leaves and on the increase in grain yield and quality (Matthies and Buchenauer, 2000).

The inclusion of strobilurin-fungicides in wheat disease control programmes for wheat has been associated with an extended flag leaf life and increased grain yields and grain protein content (Dimmock and Gooding, 2002). Strobilurins, which block electron transport in the mitochondrial respiratory chain, are also able to induce a longer duration of the green flag leaf area much longer than azoles (Ruske et al., 2003). Moreover, these fungicides have been shown to alter phytohormones level, to increase in the activity of antioxidative enzymes and the net rate of photosynthesis (Oerke et al., 2001). Strobilurins have instead shown poor efficacy in the control of FHB caused by toxigenic Fusarium spp. (Pirgozliev et al., 2002) and, furthermore, in vitro and field studies have revealed in some occasion an increase in DON accumulation (Menniti et al., 2003). In order to assure lower mycotoxin contamination in wheat grain, the application of strobilurin fungicides is only recommended in a mixture with azoles (Pirgozliev et al., 2003).

The efficacy of fungicide treatments on fungal disease control and on wheat yield in naturally-infected trials is highly variable and often unclear, since it depends on environmental and agronomic conditions, which in turn affect fungal development. The objective of this study was to evaluate the effect of the azole mixture (prochloraz + epoxiconazole) applied to wheat at the heading stage in natural field conditions, on delay in flag leaf senescence, grain yield and DON contamination. Furthermore, the above azole mixture was compared to metconazole, reported to be highly efficient in FHB control and to reduce DON accumulation, and a mixture containing strobilurin (azoxystrobin + prochloraz) highly active to control leaf diseases and to prolong the duration of the green flag leaf area. The comparison of these commercial fungicides was carried out under different climatic and agronomic conditions over a three-year experiment.

\section{Materials and Methods}

\section{Experimental site and treatments}

Experiments were carried out from 2005 to 2007 in 3 growing seasons at Riva presso Chieri (province of Turin), North West Italy ( $44^{\circ} 54^{\prime}$ $\mathrm{N}, 7^{\circ} 24^{\prime} \mathrm{E}$; altitude $262 \mathrm{~m}$ a.s.l.), in a sandy-medium textured soil, Typic Udifluvents (USDA classification).

Two adjacent experimental fields of winter wheat cultivars with high and low agronomic risks concerning FHB infection and DON contamination, were prepared each year with maize as the previous crop. The agronomic conditions were: i) high agronomic risk: a susceptible variety to FHB (cv. Serio) (Mayerle et al., 2007) planted in an untilled field, with the previous crop residues left on the soil surface, to maximize pathogen inoculum availability; ii) low agronomic risk: a medium tolerant variety to FHB (cv. Bologna) (Mayerle et al., 2007) planted in a tilled field, after an autumn ploughing $(30 \mathrm{~cm})$ which incorporated
Table 1. Main trial information on the field experiments conducted in the 2005-2008 period in Riva presso Chieri (Province of Torino, Italy).

\begin{tabular}{lccc}
$\begin{array}{l}\text { Growing } \\
\text { seasons }\end{array}$ & $\begin{array}{c}\text { Sowing } \\
\text { date }\end{array}$ & $\begin{array}{c}\text { Fungicide } \\
\text { application date }\end{array}$ & $\begin{array}{c}\text { Harvest } \\
\text { date }\end{array}$ \\
2005-2006 & October 28, 2005 & May 18, 2006 & July 5, 2006 \\
2006-2007 & October 25,2006 & May 6, 2007 & June 28, 2007 \\
\hline $2007-2008$ & November 2,2007 & May 16, 2008 & July 12, 2008 \\
\hline
\end{tabular}

maize debris in the soil, followed by disk harrowing to prepare a proper seedbed.

Both varieties were quite tolerant to powdery mildew (Blumeria graminis f.s. tritici) and are classified as medium susceptible to rusts (Puccinia spp.) and Stagonospora-Septoria complex leaf blotch (Septoria tritici and Stagonospora nodorum).

In both fields, which were characterized by different agronomic risks, different fungicides were applied at heading [growth stage (GS) 59] (Zadoks et al., 1974). A azole mixture of prochloraz (Sportak ${ }^{\circledR} 45$ EW, Basf, Italy, formulation: emulsion oil in water) applied at $0.59 \mathrm{~kg}$ active ingredient (AI) ha ${ }^{-1}+$ epoxiconazole (Opus ${ }^{\circledR}$ Basf, Torino, Italy, formulation: suspension concentrate) applied at $0.125 \mathrm{~kg}$ active ingredient (AI) ha-1 (T2), was compared with:

- an untreated control (T1);

a triazole, with high activity against Fusarium graminearum and $F$. culmorum: metconazole (Caramba ${ }^{\circledR}$, Basf, formulation: suspension concentrate), applied at $0.06 \mathrm{~kg}$ active ingredient (AI) ha ${ }^{-1}$ (T3);

a strobilurin-azole mixture, with high activity to control leaf diseases and to prolong the duration of the green flag leaf area: azoxystrobin (Amistar $^{\circledR}$, Syngenta Crop Protection, Milano, Italy, formulation: suspension concentrate), applied at $0.25 \mathrm{~kg}$ active ingredient (AI) ha ${ }^{-1}$ + prochloraz (Sportak ${ }^{\circledR} 45 \mathrm{EW}$, Basf, formulation: emulsion oil in water), applied at $0.59 \mathrm{~kg}$ active ingredient (AI) $\mathrm{ha}^{-1}$ (T4).

The fungicides were applied at the manufacturers' recommended field rates with a 4 nozzle precision sprayer (T-Jeet 110/04) using a fine mist at a slow walk to ensure an effective coverage. The delivery pressure at the nozzle was $324 \mathrm{KPa}$.

The treatments for each field condition were assigned to experimental units using a completely randomised block design with four replicates. The plot size was $7 \times 2 \mathrm{~m}$. Planting was conducted in $12 \mathrm{~cm}$ wide rows at a seeding rate of 450 seeds $\mathrm{m}^{-2}$. The weed control was conducted with isoproturon and diflufenican at wheat tillering (GS 31). Gliphosate was applied in the untilled field before direct sowing. A total of $140 \mathrm{~kg} \mathrm{~N} \mathrm{ha}^{-1}$ was applied to the plots as granular ammonium nitrate fertilizer, and was split equally between GS 31 and 39. The sowing, flowering and harvesting data for each year and each site are reported in Table 1.

The grain yields were obtained by harvesting the whole plot with a Walter Wintersteiger cereal plot combine-harvester. A subsample was taken from each plot to determine the grain moisture, test weight and thousand kernel weight (TKW). The grain yield results were adjusted to a $120 \mathrm{~g} \mathrm{~kg}^{-1}$ moisture content. The harvested grains were mixed thoroughly, and $2 \mathrm{~kg}$ grain samples were taken from each plot to analyse the DON content.

\section{Foliar disease and flag leaf greenness}

The incidence of Stagonospora-Septoria complex leaf blotch, powdery mildew and rusts was recorded for each plot, after a visual evaluation of flag leaves at the soft dough stage (GS 85). The mean affected area of each disease was classified by a 1-9 scale.

A chlorophyll meter, Hydro N-Tester ${ }^{\circledR}$ (HNT) (Yara International ASA, Oslo, Norway, formerly Hydro-Agri), was used to measure the rel- 
ative flag leaf greenness after the fungicide application.

Readings (HNT units between 0 and potentially 999) were taken using the HNT at midlength of the flag leaf from 30 randomly selected plants per plot. The HNT measurements were carried out at different ripening stages: early milk (GS 71), early dough (GS 83) and hard dough (GS 87). This last stage was used to distinguish between plots in which the flag leaves were still regularly photosynthezing and those in which translocation to the grains was almost complete.

\section{FHB symptoms and DON analyses}

FHB incidence and severity were recorded for each plot, by carrying out visual evaluations of the disease at the soft dough stage (GS 85). FHB head blight incidence was calculated as the percentage of ears with symptoms when 200 ears per plot were analysed. FHB severity was computed as the percentage of kernels per ear with symptoms. A scale of 1 to 7 was used in which each numerical value corresponds to a percentage interval of surfaces exhibiting visible symptoms of the disease according to the following schedule: $1=0-5 \%, 2=5-15 \%, 3=15-30 \%$; $4=30-50 \%, 5=50-75 \%, 6=75-90 \%, 7=90-100 \%$ (Parry et al., 1995). The FHB severity scores were converted into percentages of the ear exhibiting symptoms, replacing each score with the mid-point of the interval.

To describe what Fusarium species were most prevalent in each year and agronomic condition, the evaluation of the fungal infections was carried out on the T1 treatment using 10 ears per plot randomly collected at the soft dough stage. One hundred wheat kernels per treatment were surface disinfested for $3 \mathrm{~min}$ in a $0.5 \%$ solution of sodium hypochlorite, then rinsed 3 times with sterile water. The kernels were placed in Petri dishes containing Komada' agar (a Fusarium-selective medium) and incubated at $20^{\circ} \mathrm{C}$. The Fusarium colonies were identified after 7 to 10 days on the basis of the colony and conidial morphology, as reported by Nelson et al. (1983).

A $2 \mathrm{~kg}$ representative sample of wheat kernels collected after harvest from each plot was finely ground using a Model MLI 204 Bühler laboratory mill (Bühler S.p.A, Milano, Italy) to pass a $1 \mathrm{~mm}$ sieve. The DON concentrations were determined according to the method reported by Neumann et al. (2009) on the basis of an immunoaffinity column clean-up of the extracts and mycotoxin was determinate by HPLC/UV. Appropriate dilutions of sample extracts were necessary before loading in immunoaffinity columns for the samples contaminated with higher DON levels than $2000 \mathrm{\mu g} \mathrm{kg}^{-1}$ to avoid saturation of the DON-antibody binding sites. The detection limit of the method was $20 \mathrm{\mu g} \mathrm{kg}^{-1}$ (signalto-noise ratio of 3:1).

The reduction in DON level by means of a fungicide application can be expressed for each agronomic and environmental condition, by a parameter, efficacy (E), which is defined by the following ratio (Folcher et al., 2009):

$$
E(\%)=\left[\frac{(\text { control DON level }- \text { treatment DON level) }}{\text { control DON level }}\right] \times 100
$$

\section{Statistical analysis}

The normal distribution and homogeneity of variances were verified by performing the Kolmogorov-Smirnov normality test and the Levene test, respectively.

An analysis of variance (ANOVA) was conducted for all the year and agronomic condition combinations to isolate and evaluate the effect of the fungicide application on the HNT readings, grain yield, test weight, TKW, FHB incidence and severity and DON content. The comparisons of the means of the fungicide treatments were made using the StudentNewman-Keuls test. The statistical package SPSS for Windows, Version
16.0 (SPSS Inc., Chicago, IL, USA) was used for the statistical analysis.

The FHB incidence and severity values were arcsin square root transformed as percentage data derived from counting. The DON concentration was transformed using the $y^{\prime}=\ln (x+1)$ equation to normalize the residuals.

\section{Results}

\section{Weather conditions}

The three growing seasons showed different meteorological trends from the beginning of the stem elongation stage to harvesting (Table 2). In 2006, the precipitations were not particularly elevated, but they were concentrated close to anthesis. Frequent rainfall occurred in 2007, at the end of ripening (June), but the last rainfall was late and not able to prolong grain filling duration. In 2008, instead, the precipitations were frequent and regular from April to June, above all from the beginning of flowering to the soft dough stage, thus prolonging the harvest till the middle of July. In 2006 and 2007, the growing degree days (GDDs) were particularly high in June, thus quickening the canopy senescing process and leading to a reduction in the grain filling period and to an early maturity of the crop.

\section{Flag leaf greenness}

In the 2005-2006 and 2006-2007 growing seasons, the flag leaves in the plots not treated with fungicides (T1) were characterized, for both varieties, by medium Stagonospora-Septoria complex leaf blotch and rust attacks (classified from 3 to 5 in a 1-9 scale). In the 2007-2008 growing season, the area affected by Stagonospora-Septoria complex leaf blotch in the T1 plots was higher (from 6 to 8), while the severity of rust attacks was always low. In general, powdery mildew attack was low, in particular in the 2006-2007 growing season.

The HNT reading clearly described the greenness status of the flag leaves during the different GSs (Table 3), which is indirectly related to the foliar disease attack. A reduction in the HNT flag leaf values was observed in each growing season from GS 71 (watery ripe) to GS 87 (hard dough). In the 2005-2006 and 2006-2007 growing seasons, the decrease in HNT readings was particularly evident, mainly at the end of ripening (from GS 83 to GS 87), while in the 2007-2008 one an important reduction in HNT values was observed from GS 71 onwards.

In the 2005-2006 and 2006-2007 growing seasons, at GS 71 (watery ripe) and GS 83 (early dough), no significant differences were observed for the HNT values between the treatments. In 2008, with a higher Stagonospora-Septoria complex leaf blotch pressure, T2 and T4 treatments showed significantly $(\mathrm{P}<0.05)$ higher HNT values than $\mathrm{T} 1$ treatment at GS 71 and at GS 83 for the low risk agronomic conditions. In the 2007-2008 growing season, at GS 83 (early dough) for high risk agronomic conditions, only T4 treatment was significantly higher than T1 $(\mathrm{P}<0.05)$.The fungicide applications (T2, T3 and T4), in all the growing seasons and agronomic conditions at GS 87 (hard dough), significantly delayed flag leaf senescence compared to T1 treatment $(\mathrm{P}<0.05)$, with the exception of the 2007-2008 growing season for the T3 treatment. At GS 87 (hard dough), the azole fungicide application at heading (T2) on average increased the HNT values by $21 \%$ and $32 \%$, compared to the untreated control (T1) for low and high risk agronomic conditions, respectively. At GS 87 (hard dough), ANOVA also showed significant differences $(\mathrm{P}<0.001)$ between the fungicides: metconazole (T3) showed a significantly lower flag leaf greenness compared to T2 and T4 treatments in both agronomic conditions in 2007-2008 and compared to T4 in the high risk agronomic conditions in the 2005-2006 and the 2006-2007 growing seasons. No significant differences were observed between the fungicides in the 2005-2006 and 2006-2007 grow- 
Table 2. Rainfall, rainy days and growing degree days (GDD 0s) from March to July 2006-2008 at the research site.

\begin{tabular}{|c|c|c|c|c|c|c|c|c|c|}
\hline Year & & 2006 & & & 2007 & & & & \\
\hline Decade & $\begin{array}{c}\text { Rainfall } \\
\text { (mm) }\end{array}$ & Rainy days & $\begin{array}{l}\text { GDD 0sa } \\
\left({ }^{\circ} \mathrm{C} \mathrm{d}^{-1}\right)\end{array}$ & $\begin{array}{c}\text { Rainfall } \\
\text { (mm) }\end{array}$ & Rainy days & $\begin{array}{l}\text { GDD 0s* } \\
\left({ }^{\circ} \mathrm{C} \mathrm{d}^{-1}\right)\end{array}$ & $\begin{array}{l}\text { Rainfall } \\
\text { (mm) }\end{array}$ & Rainy days & $\begin{array}{l}\text { GDD } 0 s^{*} \\
\left({ }^{\circ} \mathrm{C} \mathrm{d}^{-1}\right)\end{array}$ \\
\hline March 1-10 & 0 & 0 & 70 & 6 & 2 & 123 & 6 & 2 & 104 \\
\hline March 11-20 & 0 & 0 & 73 & 0 & 0 & 127 & 0 & 1 & 123 \\
\hline March 21-31 & 17 & 3 & 135 & 22 & 6 & 95 & 4 & 1 & 105 \\
\hline April 1-10 & 12 & 2 & 118 & 13 & 3 & 138 & 3 & 2 & 124 \\
\hline April 11-20 & 5 & 4 & 143 & 0 & 0 & 184 & 67 & 7 & 115 \\
\hline April 21-30 & 3 & 2 & 169 & 0 & 0 & 196 & 35 & 5 & 151 \\
\hline May 1-10 & 52 & 5 & 156 & 41 & 6 & 172 & 2 & 1 & 182 \\
\hline May 11-20 & 8 & 4 & 193 & 0 & 0 & 192 & 55 & 8 & 178 \\
\hline May 21-31 & 35 & 8 & 209 & 0 & 0 & 221 & 81 & 9 & 206 \\
\hline June 1-10 & 5 & 3 & 182 & 5 & 1 & 199 & 58 & 9 & 197 \\
\hline June 11-20 & 0 & 0 & 238 & 59 & 6 & 225 & 32 & 7 & 196 \\
\hline June 21-30 & 14 & 3 & 259 & 47 & 6 & 264 & 7 & 2 & 223 \\
\hline July 1-10 & 22 & 3 & 256 & 6 & 1 & 226 & 7 & 1 & 244 \\
\hline April 21 - June 30 & 117 & 25 & 1405 & 152 & 19 & 1467 & 269 & 41 & 1332 \\
\hline
\end{tabular}

${ }^{*}$ Accumulated growing degree days for each decade using a $0^{\circ} \mathrm{C}$ base.

ing seasons, at low risk agronomic conditions.

No significant differences for the flag leaf greenness were observed at GS 87 (hard dough) between the azole mixture (T2) and the addition of a strobilurin to a azole fungicide (T4), which, on average, increased the HNT values by $22 \%$ and $39 \%$ compared to T1 treatment, respectively (Table 3).

\section{FHB symptoms and DON contamination}

In all the years, the most frequently isolated fungal species at the soft dough stage (GS 85) in the samples from the T1 plots were $F$. graminearum and $F$. culmorum (data not shown). The isolation frequency of Microdochium nivale, F. poae, and F. verticillioides was frequent every year, but the infections were limited to some kernels.

In the 2007-2008 growing season, the mean infection of T1 treatment (55\%, average of high and low risk agronomic conditions) by the above Fusarium spp. was higher than in the 2005-2006 and 2006-2007 ones, when similar low percentages of kernels infected by DONproducing Fusarium spp. were found in the T1 treatment (9\%, average of high and low risk agronomic conditions). Considering the average data of the three growing seasons for T1 treatment, the infection in the kernels from the high risk agronomic conditions was double that of the low risk conditions ( $32 \%$ vs $16 \%$ ).

The incidence and severity of the FHB symptoms recorded during the visual evaluations were higher in the 2007-2008 growing season than in the 2005-2006 and 2006-2007 growing seasons (Table 4). Considering the average data of the three growing seasons for T1 treatment, the low risk agronomic conditions clearly showed lower FHB incidence $(48 \%$ and $55 \%$ for transformed and not transformed data, respectively) than the high risk conditions ( $68 \%$ and $81 \%$ for for transformed and not transformed data, respectively). ANOVA showed a significant effect of the fungicide treatments on FHB incidence and severity for all the agronomic conditions and growing seasons $(\mathrm{P}<0.05)$.

In each condition, the azole mixture application at heading (T2) significantly reduced the FHB incidence and severity compared to the untreated control (T1), with a reduction of $19 \%$ and $13 \%$ for the two
Table 3. Effect of fungicide applications at heading on $\mathrm{N}$ tester readings on flag leaf during the ripening stages; field experiments conducted at Riva presso Chieri (Province of Torino, Italy) in the 2005-2008 period.

\begin{tabular}{|c|c|c|c|c|c|}
\hline Growing & Agronomy & Treatment* & HN & values ( & NT unit \\
\hline seasons & risk & & GS 71 & GS 83 & GS 87 \\
\hline $2005-2006$ & Low & $\mathrm{T} 1$ & $603^{\mathrm{a}}$ & $581^{\mathrm{a}}$ & $441^{b}$ \\
\hline & & $\mathrm{T} 2$ & $621^{\mathrm{a}}$ & $618^{a}$ & $511^{\mathrm{a}}$ \\
\hline & & T3 & $615^{\mathrm{a}}$ & $609^{a}$ & $494^{\mathrm{a}}$ \\
\hline & & $\mathrm{T} 4$ & $620^{a}$ & $609^{\mathrm{a}}$ & $509^{a}$ \\
\hline & & $P(\mathrm{~F})$ & 0.152 & 0.096 & $<0.001$ \\
\hline & High & $\mathrm{Tl}$ & $642^{\mathrm{a}}$ & $603^{\mathrm{a}}$ & $446^{c}$ \\
\hline & & $\mathrm{T} 2$ & $660^{\mathrm{a}}$ & $627^{\mathrm{a}}$ & $526^{\mathrm{ab}}$ \\
\hline & & T3 & $671^{\mathrm{a}}$ & $619^{a}$ & $510^{b}$ \\
\hline & & $\mathrm{T} 4$ & $657^{\mathrm{a}}$ & $626^{\mathrm{a}}$ & $556^{\mathrm{a}}$ \\
\hline & & $P(\mathrm{~F})$ & 0.299 & 0.059 & $<0.001$ \\
\hline 2006-2007 & Low & $\mathrm{Tl}$ & $590^{\mathrm{a}}$ & $572^{\mathrm{a}}$ & $322^{b}$ \\
\hline & & $\mathrm{T} 2$ & $604^{a}$ & $580^{\mathrm{a}}$ & $407^{\mathrm{a}}$ \\
\hline & & T3 & $595^{\mathrm{a}}$ & $583^{\mathrm{a}}$ & $399^{\mathrm{a}}$ \\
\hline & & T4 & $606^{\mathrm{a}}$ & $597^{\mathrm{a}}$ & $405^{\mathrm{a}}$ \\
\hline & & $P(\mathrm{~F})$ & 0.726 & 0.592 & 0.042 \\
\hline & High & $\mathrm{Tl}$ & $667^{\mathrm{a}}$ & $635^{\mathrm{a}}$ & $377^{c}$ \\
\hline & & $\mathrm{T} 2$ & $687^{\mathrm{a}}$ & $659^{\mathrm{a}}$ & $484^{a b}$ \\
\hline & & T3 & $671^{\mathrm{a}}$ & $652^{\mathrm{a}}$ & $464^{b}$ \\
\hline & & $\mathrm{T} 4$ & $683^{\mathrm{a}}$ & $673^{\mathrm{a}}$ & $517^{\mathrm{a}}$ \\
\hline & & $P(\mathrm{~F})$ & 0.656 & 0.321 & $<0.001$ \\
\hline $2007-2008$ & Low & $\mathrm{Tl}$ & $547^{b}$ & $410^{b}$ & $406^{\mathrm{b}}$ \\
\hline & & T2 & $609^{\mathrm{a}}$ & $500^{\mathrm{a}}$ & $484^{a}$ \\
\hline & & T3 & $576^{\mathrm{ab}}$ & $448^{\mathrm{b}}$ & $433^{b}$ \\
\hline & & $\mathrm{T} 4$ & $612^{\mathrm{a}}$ & $535^{\mathrm{a}}$ & $503^{\mathrm{a}}$ \\
\hline & & $P(\mathrm{~F})$ & 0.004 & $<0.001$ & $<0.001$ \\
\hline & High & $\mathrm{Tl}$ & $612^{\mathrm{a}}$ & $519^{b}$ & $363^{b}$ \\
\hline & & $\mathrm{T} 2$ & $659^{\mathrm{a}}$ & $570^{\mathrm{ab}}$ & $546^{\mathrm{a}}$ \\
\hline & & T3 & $646^{\mathrm{a}}$ & $534^{\mathrm{a}}$ & $436^{\mathrm{b}}$ \\
\hline & & $\mathrm{T} 4$ & $676^{\mathrm{a}}$ & $607^{\mathrm{a}}$ & $564^{\mathrm{a}}$ \\
\hline & & $P(\mathrm{~F})$ & 0.061 & 0.008 & $<0.001$ \\
\hline
\end{tabular}

a,b,cMeans within columns and crop techniques not followed by the same letter significantly differ (the level of significance is shown in the table); the reported values are the mean values of 4 replicate experiments; *treatment: see the text. 
parameters, respectively. The strobilurin addition to an azole fungicide did not affect the FHB control compared to the azole-only control. The application of metconazole (T3) significantly reduced the FHB severity (by $12 \%$ ) compared to the untreated control (T1) in all the environmental and agronomic conditions. On the other hand, no significant differences were observed between $\mathrm{T} 3$ and $\mathrm{T} 1$ treatments in the high risk agronomic condition in the 2005-2006 and 2006-2007 growing seasons and in the 2007-2008 growing season for either agronomic condition.

The DON contamination was generally low for the low risk agronomic conditions of the 2005-2006 and 2006-2007 seasons, with a mean contamination in the untreated control (T1) of 31 and $46 \mu \mathrm{g} \mathrm{kg}^{-1}$, respectively (Table 4). The high risk agronomic conditions clearly increased the DON content in T1 treatment, which on average was 2552 and 256 $\mu \mathrm{g} \mathrm{kg}^{-1}$, for the 2005-2006 and 2006-2007 growing seasons, respectively. The samples harvested in 2008 had the highest mean DON concentration: the mean concentration of the kernels collected from the T1 treatment plots reached 7206 and $27223 \mu \mathrm{g} \mathrm{kg}^{-1}$ in the low and high risk agronomic conditions, respectively.

In all the experiments, with the exception of the low agronomic risk condition in the 2006-2007 growing season, a significant effect $(\mathrm{P}<0.05)$ of the azole-mixture application $(\mathrm{T} 2)$ and the triazole with high activity against $F$. graminearum and $F$. culmorum (T3) was observed on DON occurrence. In both agronomic conditions in 2008, T3 treatment showed a significantly lower contamination than T2 treatment. On the other hand, the strobilurin fungicide addition to an azole fungicide (T4) only led to significant differences, compared to the untreated control (T1), in the high risk agronomic condition in the 2005-2006 growing season and in the low risk agronomic condition in the 2007-2008 one.

The difference in the efficacy (E) between the different fungicides applied in the T2 and T3 treatments was higher in the high risk conditions than in the low ones and increased moving from the 2005-2006 growing season to the 2007-2008 one. On average, the efficacy of the T2 treatment was $62 \%$ and $46 \%$, in the low and high risk agronomic conditions, while the efficacy of the T3 treatment was $69 \%$ and $58 \%$. For both agronomic conditions, the fungicide application efficacy was different over the 3 growing seasons.

The efficacy in reducing DON contamination was evaluated, on average, for the T2 treatment at 73,49 and $40 \%$ for 2005-2006, 20062007 and 2007-2008 growing seasons, respectively. The lowest efficacy was recorded in the high risk agronomic conditions of the 2007-2008 growing season, where the efficacy for T2 and T3 treatments was 25\% and $48 \%$, respectively.

\section{Yield and yield components}

ANOVA showed a significant effect of fungicide treatment on grain yield in the high risk agronomic conditions in the 2005-2006 and 20062007 growing seasons $(\mathrm{P}<0.05)$ and in both agronomic conditions in the 2007-2008 period $(\mathrm{P}<0.001)$ (Table 5). In these experiments, the azole mixture (T2) and the azole-strobilurin mixture (T4) significantly increased the grain yield compared to the untreated control (T1). In

Table 4. Effect of fungicide applications at heading on FHB incidence and severity and DON contamination of common wheat; field experiments conducted at Riva presso Chieri (Province of Torino, Italy) in the 2005-2008 period.

\begin{tabular}{|c|c|c|c|c|c|c|c|c|}
\hline Growing & Agronomy & Treatment* & & $\mathrm{ce}^{\circ}$ & $\Delta$ & & & \\
\hline seasons & risk & & $\mathrm{T}$ & N (\%) & $\mathrm{T}$ & N $(\%)$ & $\mathrm{T}$ & $\mathrm{N}\left(\mu \mathrm{gg} \mathrm{kg}^{-1}\right)$ \\
\hline $2005-2006$ & Low & $\mathrm{T} 1$ & $31.0^{\mathrm{a}}$ & 26.6 & $8.7^{\mathrm{a}}$ & 2.3 & $3.5^{\mathrm{a}}$ & 31 \\
\hline & & $\mathrm{T} 2$ & $21.4^{\mathrm{b}}$ & 13.5 & $3.0^{\mathrm{b}}$ & 0.3 & $n d^{b}$ & nd \\
\hline & & T3 & $15.5^{b}$ & 7.5 & $3.7^{\mathrm{b}}$ & 0.7 & $n d^{b}$ & nd \\
\hline & & $\mathrm{T} 4$ & $11.8^{b}$ & 5.6 & $1.7^{\mathrm{b}}$ & 0.1 & $3.2^{\mathrm{a}}$ & 23 \\
\hline & & $P(\mathrm{~F})$ & 0.001 & & 0.002 & & $<0.001$ & \\
\hline & High & $\mathrm{T} 1$ & $54.3^{\mathrm{a}}$ & 65.3 & $18.8^{\mathrm{a}}$ & 10.6 & $7.8^{\mathrm{a}}$ & 2552 \\
\hline & & T2 & $30.3^{b}$ & 26.3 & $6.7^{\mathrm{b}}$ & 1.7 & $6.9^{\mathrm{b}}$ & 981 \\
\hline & & $\mathrm{T} 3$ & $36.0^{\mathrm{ab}}$ & 35.6 & $8.0^{\mathrm{b}}$ & 2.1 & $6.8^{\mathrm{b}}$ & 880 \\
\hline & & $\mathrm{T} 4$ & $32.9^{\mathrm{b}}$ & 31.6 & $9.7^{\mathrm{b}}$ & 3.6 & $6.7^{\mathrm{b}}$ & 785 \\
\hline & & $P(\mathrm{~F})$ & 0.044 & & 0.006 & & $<0.001$ & \\
\hline 2006-2007 & Low & $\mathrm{T} 1$ & $46.2^{\mathrm{a}}$ & 52.0 & $11.0^{\mathrm{a}}$ & 10.3 & $3.8^{\mathrm{a}}$ & 46 \\
\hline & & T2 & $33.0^{\mathrm{b}}$ & 29.8 & $4.8^{b}$ & 2.1 & $3.2^{\mathrm{a}}$ & 24 \\
\hline & & T3 & $34.7^{\mathrm{b}}$ & 32.5 & $4.7^{\mathrm{b}}$ & 2.0 & $3.1^{\mathrm{a}}$ & 21 \\
\hline & & $\mathrm{T} 4$ & $36.5^{b}$ & 35.4 & $5.2^{\mathrm{b}}$ & 2.4 & $3.8^{\mathrm{a}}$ & 43 \\
\hline & & $P(\mathrm{~F})$ & $<0.001$ & & $<0.001$ & & 0.406 & \\
\hline & High & $\mathrm{T} 1$ & $64.6^{\mathrm{a}}$ & 81.1 & $22.4^{\mathrm{a}}$ & 14.9 & $5.5^{\mathrm{a}}$ & 256 \\
\hline & & T2 & $44.3^{b}$ & 48.8 & $9.2^{\mathrm{b}}$ & 2.6 & $4.8^{\mathrm{b}}$ & 125 \\
\hline & & T3 & $54.4^{\mathrm{ab}}$ & 65.6 & $11.9^{b}$ & 4.4 & $4.6^{\mathrm{b}}$ & 102 \\
\hline & & $\mathrm{T} 4$ & $43.0^{\mathrm{b}}$ & 46.6 & $9.4^{\mathrm{b}}$ & 2.9 & $5.7^{\mathrm{a}}$ & 286 \\
\hline & & $P(\mathrm{~F})$ & 0.002 & & $<0.001$ & & 0.026 & \\
\hline $2007-2008$ & Low & $\mathrm{T} 1$ & $68.1^{\mathrm{a}}$ & 85.8 & $17.0^{\mathrm{a}}$ & 8.7 & $8.9^{\mathrm{a}}$ & 7206 \\
\hline & & T2 & $46.8^{b}$ & 53.1 & $7.7^{\mathrm{b}}$ & 1.8 & $8.1^{\mathrm{c}}$ & 3249 \\
\hline & & T3 & $58.7^{\mathrm{a}}$ & 72.2 & $10.2^{b}$ & 3.1 & $7.7^{\mathrm{d}}$ & 2177 \\
\hline & & T4 & $45.5^{\mathrm{b}}$ & 50.8 & $7.6^{\mathrm{b}}$ & 1.8 & $8.5^{\mathrm{b}}$ & 5005 \\
\hline & & $P(\mathrm{~F})$ & $<0.001$ & & $<0.001$ & & $<0.001$ & \\
\hline & High & $\mathrm{T} 1$ & $85.9^{\mathrm{a}}$ & 98.0 & $48.3^{\mathrm{a}}$ & 55.7 & $10.2^{\mathrm{a}}$ & 27,223 \\
\hline & & $\mathrm{T} 2$ & $65.9^{\mathrm{b}}$ & 83.3 & $15.5^{\mathrm{b}}$ & 7.3 & $9.9^{\mathrm{b}}$ & 20,380 \\
\hline & & T3 & $73.9^{\mathrm{ab}}$ & 91.6 & $17.7^{\mathrm{b}}$ & 9.4 & $9.6^{\mathrm{c}}$ & 14,142 \\
\hline & & $\mathrm{T} 4$ & $68.4^{b}$ & 85.0 & $17.7^{\mathrm{b}}$ & 9.3 & $10.2^{\mathrm{a}}$ & 25,898 \\
\hline & & $P(\mathrm{~F})$ & 0.007 & & $<0.001$ & & $<0.001$ & \\
\hline
\end{tabular}

a,b,c Means within columns and crop techniques not followed by the same letter significantly differ (the level of significance is shown in the table); the reported values are the mean values of 4 replicate experiments; the FHB incidence and severity means reported are transformed $\left(T ; y^{\prime}=\arcsin \sqrt{ } x^{*} 180 / \pi\right)$ and not transformed $(N)$ values; the DON contamination means are transformed $\left[\mathrm{T} ; \mathrm{y}^{\prime}=\ln (\mathrm{x}+1)\right]$ and not transformed (N) values; *treatment: see the text; ${ }^{\circ}$ FHB incidence was calculated as the percentage of ears with symptoms of disease at the soft dough stages (GS 85); ${ }^{\sharp}$ FHB severity was calculated as the percentage of kernels per ear with symptoms of disease at the soft dough stages (GS 85); nd, not detected. The detection limit was $20 \mu \mathrm{g} \mathrm{kg}{ }^{-1}$. 
the high risk agronomic condition in the 2005-2006 and 2006-2007 growing seasons, T2 and T4 treatments increased the grain yield by $11 \%$ compared to $\mathrm{T} 1$. In the 2007-2008 growing season, T1 and T4 treatments significantly increased the grain yield, on average, by $32 \%$ and $60 \%$, in the low and high risk agronomic conditions, respectively. The application of metconazole (T3) only significantly increased the grain yield compared to the untreated control (T1) in 2007-2008, with an increase of $23 \%$ and $53 \%$ in the low and high risk conditions, respectively. Moreover, the T3 treatment showed a significantly lower grain yield than the T2 and T4 treatments in the high risk agronomic conditions of the 2006-2007 growing season and in both agronomic conditions in 2007-2008.

The test weight was generally lower in the grain samples harvested in 2008 than those of 2006 and 2007, and in the high risk agronomic conditions than in the low ones, as a consequence of the higher FHB and foliar disease pressure (Table 5). ANOVA showed significant differences between the treatments concerning the test weight in the experiments conducted at low risk conditions in the 2005-2006 and 2007-2008 growing seasons. In both cases, T2 and T4 treatments significantly increased the test weight compared to $\mathrm{T} 1$.

TKW was significantly increased by the T2 and T4 treatments compared to $\mathrm{T} 1$ in the high risk agronomic conditions of each growing season and also in the low agronomic conditions in 2007-2008 (Table 5). The T3 treatment showed a significantly higher TKW than T1 in the high risk condition in the 2005-2006 and 2007-2008 growing seasons. In the 2007-2008 growing season, in both agronomic conditions, the TKW of the T3 treatment was significantly lower than the T2 and T3 treatments.

\section{Discussion}

The results of these experiments, conducted over three years characterized by extremely different meteorological trends, underline the important link between fungicide efficacy and environmental and agronomic conditions, factors which influence fungal disease pressure.

The prochloraz and epoxiconazole mixture application at heading confirms a clear effect on delaying flag leaf senescence, reducing FHB incidence and severity and DON contamination and increasing grain yield. These effects were greater with higher ear and leaf disease pressure. The increase in wheat yield, as a consequence of fungicide application at heading in naturally-infected conditions, are in agreement with those of a previous research (Blandino et al., 2006) and with those of Ransom and McMullen (2008), who observed an increase in grain yield of $11 \%$ and $5 \%$ in the lowest fungal pressure and of $27 \%$ and $44 \%$ in the highest one, respectively. In durum wheat cultivated in North Italy, the application of prochloraz and ciproconazole mixture at heading led to yield advantages comprise between $8 \%$ and $40 \%$ (Blandino et al., 2009). Focusing on foliar disease, Gooding et al. (2000) observed that the fungicide application increased grain yield by $13 \%$ (average of 9 trials), but the yield was increased by $47 \%$ in the experiment with the strongest attack to flag leaf. Although more than $80 \%$ of the variance in yield was due to the environment, Milus (1994) reported that a tebuconazole or propiconazole application to control leaf rust and septoria leaf blotch, on average, increased grain yield by $14 \%$, while only $3 \%$ of variance was due to the interaction between environment and treatment. In our experiments, the grain yields were not significantly increased by the azole mixture when it was applied with a low disease pressure.

On the other hand, the DON contamination was reduced by the fungicide to a greater extent in the low risk agronomic and environmental conditions than in the high risk ones, confirming the data of Mesterhazy et al. (2003), who achieved better efficacy when fungicides
Table 5. Effect of fungicide applications at heading on grain yield, test weight and thousand grain weight (TKW) of common wheat; field experiments conducted at Riva presso Chieri (Province of Torino, Italy) in the 2005-2008 period.

\begin{tabular}{|c|c|c|c|c|c|}
\hline $\begin{array}{l}\text { Growing } \\
\text { seasons }\end{array}$ & $\begin{array}{l}\text { Agronomy } \\
\text { risk }\end{array}$ & Treatment* & $\begin{array}{l}\text { Grain } \\
\text { yield } \\
\mathrm{t} \mathrm{ha}^{-1}\end{array}$ & $\begin{array}{c}\text { Test } \\
\text { weight } \\
\mathrm{kg} \mathrm{h}^{-1}\end{array}$ & $\begin{array}{c}\text { TKW } \\
\text { g }\end{array}$ \\
\hline $2005-2006$ & High & $\begin{array}{c}\mathrm{T} 1 \\
\mathrm{~T} 2 \\
\mathrm{~T} 3 \\
\mathrm{~T} 4 \\
P(\mathrm{~F}) \\
\mathrm{T} 1 \\
\mathrm{~T} 2 \\
\mathrm{~T} 3 \\
\mathrm{~T} 4 \\
P(\mathrm{~F})\end{array}$ & $\begin{array}{c}8.2^{\mathrm{a}} \\
8.5^{\mathrm{a}} \\
8.4^{\mathrm{a}} \\
8.4^{\mathrm{a}} \\
0.346 \\
7.1^{\mathrm{b}} \\
7.9^{\mathrm{a}} \\
7.2^{\mathrm{b}} \\
7.9^{\mathrm{a}} \\
<0.001\end{array}$ & $\begin{array}{c}83.7^{\mathrm{b}} \\
84.3^{\mathrm{a}} \\
84.2^{\mathrm{ab}} \\
84.4^{\mathrm{a}} \\
0.017 \\
82.9^{\mathrm{a}} \\
83.2^{\mathrm{a}} \\
82.7^{\mathrm{a}} \\
84.1^{\mathrm{a}} \\
0.096\end{array}$ & $\begin{array}{l}33.5^{\mathrm{a}} \\
33.0^{\mathrm{a}} \\
33.5^{\mathrm{a}} \\
34.2^{\mathrm{a}} \\
0.465 \\
36.5^{\mathrm{b}} \\
39.7^{\mathrm{a}} \\
40.9^{\mathrm{a}} \\
40.7^{\mathrm{a}} \\
0.004\end{array}$ \\
\hline 2006-2007 & High & $\begin{array}{c}\text { T1 } \\
\text { T2 } \\
\text { T3 } \\
\text { T4 } \\
P(\mathrm{~F}) \\
\text { T1 } \\
\text { T2 } \\
\text { T3 } \\
\text { T4 } \\
P(F)\end{array}$ & $\begin{array}{c}6.0^{\mathrm{a}} \\
6.2^{\mathrm{a}} \\
6.0^{\mathrm{a}} \\
6.4^{\mathrm{a}} \\
0.081 \\
4.9^{\mathrm{b}} \\
5.4^{\mathrm{a}} \\
5.1^{\mathrm{ab}} \\
5.4^{\mathrm{a}} \\
0.020\end{array}$ & $\begin{array}{l}73.9^{\mathrm{a}} \\
75.8^{\mathrm{a}} \\
73.5^{\mathrm{a}} \\
74.8^{\mathrm{a}} \\
0.750 \\
71.0^{\mathrm{a}} \\
72.9^{\mathrm{a}} \\
72.1^{\mathrm{a}} \\
72.7^{\mathrm{a}} \\
0.318\end{array}$ & $\begin{array}{l}28.6^{\mathrm{a}} \\
28.6^{\mathrm{a}} \\
28.0^{\mathrm{a}} \\
28.0^{\mathrm{a}} \\
0.733 \\
34.0^{\mathrm{b}} \\
36.3^{\mathrm{a}} \\
35.4^{\mathrm{ab}} \\
36.6^{\mathrm{a}} \\
0.049\end{array}$ \\
\hline $2007-2008$ & Low & $\begin{array}{c}\text { T1 } \\
\text { T2 } \\
\text { T3 } \\
\text { T4 } \\
P(\mathrm{~F}) \\
\mathrm{T} 1 \\
\mathrm{~T} 2 \\
\mathrm{~T} 3 \\
\mathrm{~T} 4 \\
P(\mathrm{~F})\end{array}$ & $\begin{array}{c}4.5^{\mathrm{c}} \\
6.6^{\mathrm{a}} \\
5.8^{\mathrm{b}} \\
6.6^{\mathrm{a}} \\
<0.001 \\
1.9^{\mathrm{c}} \\
4.5^{\mathrm{a}} \\
4.0^{\mathrm{b}} \\
4.7^{\mathrm{a}} \\
<0.001 \\
\end{array}$ & $\begin{array}{l}64.5^{\mathrm{b}} \\
72.4^{\mathrm{a}} \\
70.5^{\mathrm{a}} \\
71.8^{\mathrm{a}} \\
0.005 \\
65.5^{\mathrm{a}} \\
69.2^{\mathrm{a}} \\
67.9^{\mathrm{a}} \\
68.6^{\mathrm{a}} \\
0.082\end{array}$ & $\begin{array}{c}24.2^{\mathrm{b}} \\
28.0^{\mathrm{a}} \\
25.3^{\mathrm{b}} \\
28.0^{\mathrm{a}} \\
0.002 \\
22.7^{\mathrm{c}} \\
28 .^{\mathrm{a}} \\
26.1^{\mathrm{b}} \\
28.4^{\mathrm{a}} \\
<0.001\end{array}$ \\
\hline
\end{tabular}

a,b,cMeans within columns and crop techniques not followed by the same letter significantly differ (the level of significance is shown in the table). The reported values are the mean values of 4 replicate experiments; *treatment: see the text.

were applied to a medium tolerant cultivar than when applied to a susceptible one. In our experiment, the fungicide efficacy to minimize the DON content was higher each year in the low agronomic risk condition for the FHB infection (combination of ploughing and medium tolerant cultivar) than in the high one. McMullen et al. (2008) reported that a fungicide application reduced the DON content by $31 \%$ when the previous crop was wheat, while a reduction of $57 \%$ occurred when it was canola, which determines a clearly lower FHB infection. On the other hand, our data are in contrast with a similar experiment conducted over 2 years in Germany (Koch et al., 2006), where a tebuconazole treatment only slightly diminished the DON concentration (by 14\%) when a medium tolerant cultivar was cultivated after ploughing, while spraying a fungicide decreased the DON content by $71 \%$ when a susceptible cultivar was grown with minimum tillage conditions.

The azole mixture, compared to a triazole with high activity action against DON producing fungi (metconazole), showed a similar and sometimes higher capacity to reduce FHB incidence and severity, Similar results have also been reported by Pirgozliev et al. (2008), concerning a naturally-infected experiment, where $F$. graminearum and $F$. culmorum were the predominant species. On the other hand, the DON content was always higher when prochloraz + epoxiconazole was applied, compared to the metconazole application, although significant differences between these fungicides, for DON content, were only observed in the more rainy growing seasons. Our findings are in agree- 
ment with other field investigations (Paul et al., 2008), which reported that metconazole was the most effective treatment, with an efficacy of $45 \%$, while the other active substance efficacies were $43 \%$ (prothioconazole), $23 \%$ (tebuconazole) and 12\% (propiconazole). In our study, the difference in the efficacy to minimize DON contamination, between a specific fungicide for this purpose and a standard one, clearly increased with more favourable agronomic and environmental conditions for FHB and DON contamination. Compared to a strobilurinazole mixture, which was selected as a reference in our study for a fungicide with elevated action to prolong green flag leaf life, the azole mixture showed insignificant differences for the HNT reading at the end of the filling period and for grain yield, test weight and TKW, confirming the results of other researches (Dimmock and Gooding, 2002; Blandino and Reyneri, 2009). Furthermore, in our trial, the strobilurin-azole application showed a numerically higher flag leaf greenness at GS87 than the azole mixture in the untilled plots or in the year with the highest foliar disease pressure. In other experiments, the addition of a strobilurin fungicide, compared to triazole alone, significantly delayed the senescence of the flag leaves and consistently increased yields and TGW (Gooding et al., 2000; Ruske et al., 2004). The lack of a clear effect associated with the strobilurin addition compared to the azole fungicide, even for higher disease pressure conditions, could be related to the use of epoxiconazole in the mixture applied in our study. This fungicide, among the azoles, shows the best efficacy in controlling foliar disease (Mercer and Ruddock, 1998). On the other hand, Bertelsen et al. (2001) reported a significantly higher capacity of azoxystrobin to maintain the green leaf area longer than epoxiconazole. As expected, metconazole on its own showed a lower efficacy in delaying flag leaf senescence and in lowering the grain yield compared to the azole mixture, while, as expected, the addition of a strobilurin to an azole application at heading significantly increased DON contamination compared to the treatment with the azole on its own. Both these effects were clearly amplified when the agronomic and climatic conditions led to higher fungal disease pressure. Another aspect, which was not considered in our trial, could involve verifying whether the mixture between a fungicide with high activity against DON producing fungi and a strobilurin in natural infected conditions could be able to reduce the defects of each fungicide and obtain an overall better performance of the fungicide treatment. Pirgozliev et al. (2008), in artificially inoculated trials, reported that both metconazole and tebuconazole reduced DON in grains by $50-60 \%$ more than applying azoxystrobin on its own, or in a mixture with either of the two triazole fungicides. Moreover, the collected data also demonstrated that the most effective fungicide applied in this trial may not provide sufficient control of DON contamination, if the environmental or agronomic conditions are extremely favourable for fungal development.

In conclusion, our results, obtained under naturally-infected field conditions, provide useful information to help evaluate the effects of fungicide applications at heading on wheat yield and sanity in distinct scenarios for FHB and foliar diseases pressure. Since environmental (weather conditions, fungal population) and agronomic (mainly cultivar susceptibility to FHB and foliar disease, crop rotation, soil tillage) factors clearly influence the performances of fungicide applications at heading, direct wheat protection programmes need to carefully take into account the probable level of fungal diseases, on the basis of predictive Fusarium head blight and related mycotoxin contamination models, and on the basis of the whole cropping system applied.

\section{References}

Bertelsen J.R., de Neergaard E., Smedegaard-Petersen V., 2001. Fungicidal effects of azoxystrobin and epoxiconazole on phyllosh- pere fungi, senescence and yield of winter wheat. Plant Pathol. 50:190-205.

Blandino M., Minelli L., Reyneri A., 2006. Strategies for the chemical control of Fusarium head blight: effect on yield, alveographic parameters and deoxynivalenol contamination in winter wheat grain. Eur. J. Agron. 25:193-201.

Blandino M., Pilati A., Reyneri A. 2009. Effect of foliar treatments to durum wheat on flag leaf senescence, grain yield, quality and DON contamination in North Italy. Field Crop Res. 114:214-222.

Blandino M., Reyneri, A., 2009. Effect of fungicide and foliar fertilizer application to winter wheat at anthesis on flag leaf senescence, grain yield, flour bread-making quality and DON contamination. Eur. J. Agron. 30:275-282

Bottalico A., Perrone G., 2002. Toxigenic Fusarium species and mycotoxins associated with head blight in small-grain cereals in Europe. Eur. J. Plant Pathol. 108:611-624.

Champeil A., Dore T., Fourbet J.F., 2004a. Fusarium head blight: epidemiological origin of the effects of cultural practices on head blight attacks and the production of mycotoxins by Fusarium in wheat grains. Plant Sci. 166:1389-1415.

Champeil A., Fourbet J.F., Dore T., Rossignol L., 2004b. Influence of cropping system on Fusarium head blight and mycotoxin levels in winter wheat. Crop Prot. 23:531-537.

Dimmock J.P.R.E., Gooding M.J., 2002. The effect of fungicides on rate and duration of grain filling in winter wheat in relation to maintenance of flag leaf green area. J. Agric. Sci. 138:1-16.

Edwards S.G., Pirgozliev S.R., Hare M.C., Jenkinson P., 2001. Quantification of trichothecene-producing Fusarium species in harvest grain by competitive PCR to determine the efficacy of fungicides against Fusarium head blight of winter wheat. Appl. Environ. Microbiol. 67:1575-1580.

Folcher L., Jarry M., Weissenberger A., Gérault F., Eychenne N., Delos M., Regnault-Roger C., 2009. Comparative activity of agrochemical treatments on mycotoxin levels with regard to corn borers and Fusarium mycoflora in maize (Zea mays L.) fields. Crop Prot. 28:302-308.

Gooding M.J., Dimmock J.P.R.E., France J., Jones S.A., 2000. Green leaf area decline of wheat flag leaves: the influence of fungicides and relationships with mean grain and grain yield. Ann. Appl. Biol. 136:77-84.

Klix M.B., Verreet J.A., Beyer M., 2007. Comparison of the declining triazole sensitivity of Gibberella zeae and increased sensitivity achieved by advances in triazole fungicide development. Crop Prot. 26:683-690.

Koch H.J., Pringas C., Maerlaender B., 2006. Evaluation of environmental and management effects on Fusarium head blight infection and deoxynivalenol concentration in the grain of winter wheat. Eur. J. Agron. 24:357-366.

Krupinsky J.M., Tanaka D.L., Lares M.T., Merrill S.D., 2004. Leaf spot disease of barley and spring wheat as influenced by preceding crops. Agron. J. 96:259-266.

Loyce C., Meynard J.M. Bouchard C., Rolland B., Lonnet P., Bataillon P., Bernicot M.H., Bonnefoy M., Charrier X., Debote B., Demarquet T., Duperrier B., Félix I., Heddadj D., Leblanc 0., Leleu M., Mangin P., Méausoone M., Doussinault G., 2008. Interaction between cultivar and crop management effects on winter wheat disease, lodging and yield. Crop Prot. 27:1131-1142.

Maiorano A., Blandino M., Reyneri A., Vanara F., 2008. Effects of maize residues on the Fusarium spp. infection and deoxynivalenol (DON) contamination of wheat grain. Crop Prot. 27:182188.

Matthies A., Buchenauer H., 2000. Effect of tebuconazole (Folicur) and prochloraz (Sportak) treatments on Fusarium head scab development, yield, and deoxynivalenol (DON) content in grains 
of wheat following artificial inoculation with Fusarium culmorum. J. Plant Dis. Protect. 107:33-52.

Mayerle M., Pancaldi D., Haidukowski M., Pascale M., Ravaglia S., 2007. Fusariosi e grano tenero: quali sono le varietà più resistenti. L'Informatore Agrario 32:45-49.

Menniti A.M., Pancaldi D., Maccaferri M., Casalini L., 2003. Effect of fungicides on Fusarium head blight and deoxynivalenol content in durum wheat grain. Eur. J. Plant Pathol. 109:109-115.

Mercer P.C., Ruddock A. 1998. Evaluation of azoxystrobin and a range of conventional fungicides on yield, Septoria tritici and senescence in winter wheat. Ann. Appl. Biol. 132(Suppl.):24-25.

Mesterhazy A., Bartok T., Lamper C., 2003. Influence of wheat cultivar, species of Fusarium, and isolate aggressiveness on the efficacy of fungicides for control of Fusarium head blight. Plant Dis. 87:1107-1115.

Milus E.A., 1994. Effect of foliar fungicides on disease control, yield and test weight of soft red winter wheat. Crop Prot. 13:291-295.

Milus E.A., Parsons C.E., 1994. Evaluation of foliar fungicides for controlling Fusarium head blight of wheat. Plant Dis. 78:697-699.

Nelson P.E., Toussoun T.A., Marasas W.F.O., 1983. Fusarium species: an illustrated manual for identification. PennState University Press, University Park, PA, USA.

Neumann G., Lombaert G.A., Kotello S., Fedorowich N., 2009. Determination of deoxynivalenol in soft wheat by immunoaffinity column cleanup and LC-UV detection: interlaboratory study. J. AOAC INT. 92 181-189.

Oerke E.C., Beck C., Dehne H.W., 2001. Physiological effects of strobilurins on wheat yield. Phytopathology 91:67-71.

Parry D.W., Jenkinson P., McLeod L., 1995. Fusarium ear blight (scab) in small grain cereal - Review. Plant Path. 44:207-238.

Paul P.A., Lipps P.E., Hershman D.E., McMullen M.P., Draper M.A., Madden L.V., 2008. Efficacy of triazole-based fungicides for Fusarium Head Blight and deoxynivalenol control in wheat: a multivariate meta-analysis. Phytopathology 98:999-1011.

Pirgozliev S.R., Edwards S.G., Hare M.C., Jenkinson P., 2002. Effect of dose rate of azoxystrobin and metconazole on the development of
Fusarium head blight and the accumulation of deoxynivalenol (DON) in wheat grain. Eur. J. Plant Pathol. 108:469-478.

Pirgozliev S.R., Edwards S.G., Hare M.C., Jenkinson P., 2003. Strategies for the control of Fusarium head blight in cereals. Eur. J. Plant Pathol. 109:731-742.

Pirgozliev S.R., Ray R.V., Edwards S.G., Hare M.C., Jenkinson P., 2008. Effect of timing of fungicide application on the development of Fusarium Head Blight and the accumulation of deoxynivalenol (DON) in winter wheat grain. Cereal Res. Commun. 36:289-299.

Ransom J.K., McMullen M.V., 2008. Yield and disease control on hard winter wheat cultivars with foliar fungicides. Agron. J. 100:11301137.

Richards R.A. 2000. Selectable traits to increase crop photosynthesis and yield of grain crops. J. Exp. Bot. 51:447-458.

Robert C., Bancal M.-O., Nicolas P., Lannou C., Ney B., 2004. Analysis and modelling effects of leaf rust and Septoria tritici blotch on wheat growth. J. Exp. Bot. 55:1079-1094.

Ruske R.E., Gooding M.J., Jones S.A., 2003. The effect of adding picoxystrobin, azoxystrobin and nitrogen to a triazole programme on disease control, flag leaf senescence, yield and grain quality 0 winter wheat. Crop Prot. 22:975-987.

Ruske R.E., Gooding M.J., Dobraszczyk B.J., 2004. Effect of triazole and strobilurin fungicide programmes with and without late-season nitrogen fertilizer, on the baking quality of Malacca winter wheat. J. Cereal Sci. 40:1-8.

Simpson D.R., Weston G.E., Turner J.A., Jennings P., Nicholson P., 2001. Differential control of head blight pathogens of wheat by fungicides and consequences for mycotoxins contamination of grain. Eur. J. Plant Pathol. 107:421-431.

Tóth B., Kaszonyi G., Bartok T., Varga J., Mesterhazy A., 2008. Common resistance of wheat to members of the Fusarium graminearum species complex and F. culmorum. Plant Breeding 127:1-8.

Zadoks J.C., Chang T.T., Konzak C.F., 1974. A decimal code for the growth stages of cereals. Weed Res. 14:415-421. 